\title{
Polymorphism of the merozoite surface protein-1 block 2 region in Plasmodium falciparum isolates from Mauritania
}

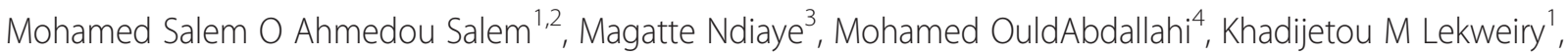 \\ Hervé Bogreau ${ }^{5,6,7}$, Lassana Konaté ${ }^{2}$, Babacar Faye ${ }^{3}$, Oumar Gaye ${ }^{3}$, Ousmane Faye ${ }^{2}$ \\ and Ali O Mohamed Salem O Boukhary ${ }^{1 *}$
}

\begin{abstract}
Background: The genetic diversity of Plasmodium falciparum has been extensively studied in various parts of the world. However, limited data are available from Mauritania. The present study examined and compared the genetic diversity of $P$. falciparum isolates in Mauritania.

Methods: Plasmodium falciparum isolates blood samples were collected from 113 patients attending health facilities in Nouakchott and Hodh El Gharbi regions. K1, Mad20 and RO33 allelic family of msp-1 gene were determined by nested PCR amplification.
\end{abstract}

Results: K1 family was the predominant allelic type carried alone or in association with Ro33 and Mad20 types (90\%; 102/113). Out of the 113 P. falciparum samples, 93(82.3\%) harboured more than one parasite genotype. The overall multiplicity of infection was 3.2 genotypes per infection. There was no significant correlation between multiplicity of infection and age of patients. A significant increase of multiplicity of infection was correlated with parasite densities.

Conclusions: The polymorphism of $P$. falciparum populations from Mauritania was high. Infection with multiple P. falciparum clones was observed, as well as a high multiplicity of infection reflecting both the high endemicity level and malaria transmission in Mauritania.

Keywords: Plasmodium falciparum, Malaria, Genetic diversity, Multiplicity of infection, msp-1 gene, Mauritania

\section{Background}

Malaria remains a public health problem in Mauritania with an estimated of 250,000 clinical cases reported annually [1]. Data reported during the two last decades shown an increase in malaria cases from 26.933 in 1990 to 188.025 in 2006 [2]. The majority of infection is due to Plasmodium falciparum, which is responsible for more than $80 \%$ of malaria cases and entomological studies show that the main vector is Anopheles gambiae [1,3-7]. Throughout the country malaria is endemic with a seasonal transmission from July to October, as is the case

\footnotetext{
* Correspondence: alimedsalem@gmail.com

'Laboratoire de Biotechnologie, Faculté des Sciences et Techniques, Université des Sciences, de Technologie et de Médecine, Nouakchott, PO Box 5026, Nouakchott, Mauritanie

Full list of author information is available at the end of the article
}

in the most Sahelian countries $[1,8]$. The country can be divided into three epidemiological strata: the Saharan region in the north, representing $80 \%$ of the country's area with annual rainfall less than $100 \mathrm{~mm}$, where malaria transmission is rare. A sero-epidemiological study conducted in 1980s showed prevalence between 8 and $15 \%$ of history of infection with $P$. falciparum in this zone [9]. In the Sahelian zone, located in the southern part, between Nouakchott and Nema (annual rainfall $100-300 \mathrm{~mm}$ ), malaria is unstable and seasonal transmission during rainy season can cause deadly epidemics $[3,4]$. The Sudanian region in the South, bordering with the Senegal River Valley (annual rainfall 300-600 mm), an agricultural area, including rice, where malaria transmission is stable, but with a significant difference in prevalence between the rainy season and the dry season

\section{() Biomed Central}


[1]. Despite the enormous efforts that have been directed toward malaria control and prevention [10], multiple factors including insecticide resistance in anopheline vectors, the lack of effective vaccines, and the emergence and rapid spread of drug-resistant strains are the major problems for controlling and preventing malaria.

Therefore, the development of an effective malaria vaccine continues to be urgently needed. However, extensive genetic diversity in natural malaria parasite populations is a major obstacle for the development of an effective vaccine against these parasites, because antigenic diversity limits the efficiency of acquired protective immunity to malaria [11,12]. Many P. falciparum proteins have been proposed for use as vaccine candidate antigens, but the merozoite surface protein-1 (MSP-1) has been most studied $[13,14]$. Extensive genetic polymorphism of the $m s p-1$ gene has been identified in $P$. falciparum isolates worldwide [15-17]. It is important to investigate the diversity of $m s p-1$ gene, in different geographic areas for the further development of effective malaria vaccine. The gene coding the merozoite surface protein 1 ( $m s p-1)$ has been widely used as a marker for genotyping parasite populations [18-20]. In P. falciparum, the surface protein MSP-1 (around $190 \mathrm{kDa}$ ) plays an important role in erythrocyte invasion by the merozoite [21]. The protein is a principal target of human immune responses [22] and is a promising candidate for a blood stage subunit vaccine $[14,23]$. The $m s p-1$ gene occurs as one of three distinct allelic families: K1, MAD20 and Ro33 [24]. It has 7 variable blocks that are separated either by conserved or semi-conserved regions. Block 2, a region near the N-terminal of MSP-1, is the most polymorphic part of the antigen and appears to be under the strongest diversifying selection within natural populations [21].

The genetic diversity of $P$. falciparum has been extensively studied in various parts of the world, but limited data are available from Mauritania. The only study on $P$. falciparum population genetic structure using $m s p-1$, msp-2 and glurp markers date back 15 years [4]. The present study examined and compared the genetic diversity of $P$. falciparum isolates among febrile patients attending health facilities in Nouakchott and Hodh El Gharbi region in Mauritania, during the peak of malaria transmission, using the polymorphic gene encoding for the merozoite surface protein-1 (MSP-1).

\section{Methods}

Study sites

The study was conducted in Hodh El Gharbi (HG), south-east Mauritania, and in Nouakchott, the capital city of Mauritania during the rainy season in SeptemberOctober 2010 (Figure 1). HG region (latitude $16^{\circ} 13^{\prime}$ 02 " N, longitude $9^{\circ} 54^{\prime} 44^{\prime \prime} \mathrm{W}$ ) covers a surface area of $53,000 \mathrm{~km}^{2}$ with four departments, (Aïon, Kobeni, Tintane and Tamchekett). The population of HG is approximately 212,156 inhabitants [25]. Most residents are subsistence animal breeders and farmers. The climate in HG region is Sahelian characterized by a long dry season, lasting from October to June, and a rainy season extending from July to September. It receives between $200-300 \mathrm{~mm}$ of annual rainfall. The monthly mean temperature ranges from 24 to $37^{\circ} \mathrm{C}$. A transmauritanian highway of $1,200 \mathrm{~km}$ from

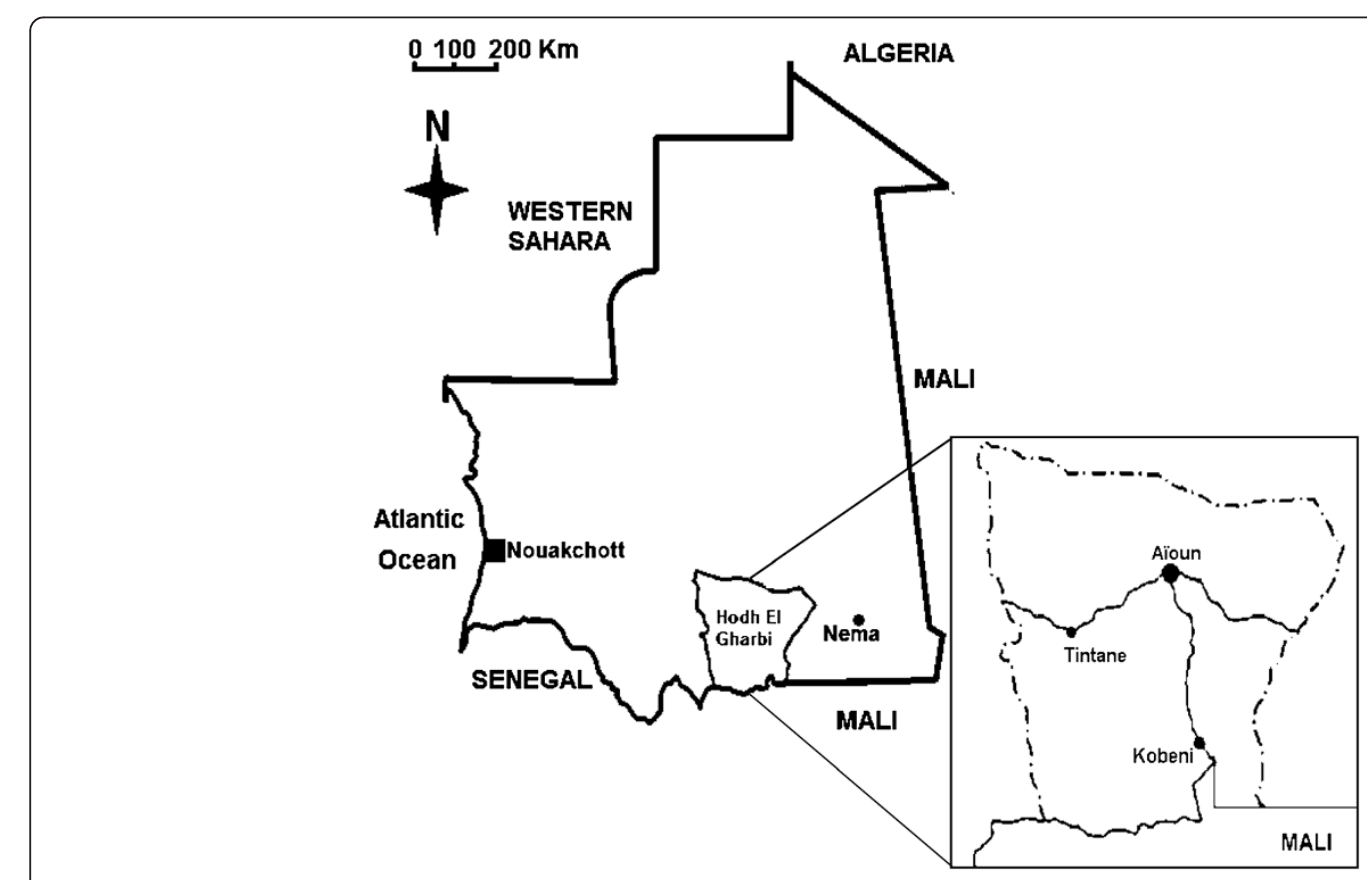

Figure 1 Map of Mauritania showing the study sites. 
Nouakchott to Nema in the far south-eastern region of the country passes through HG from west to east. HG region can also be reached on a paved road from Nioro du Sahel in Mali. The region is poorly served by health service facilities. There is only one hospital in Aioun and one health centre in each department. Nouakchott $\left(18^{\circ} .11^{\prime} \mathrm{N}\right.$; $\left.16^{\circ} .16^{\prime} \mathrm{W}\right)$, is situated in a Saharan zone, near the Atlantic coast at an average altitude of $7 \mathrm{~m}$. It comprises nine districts and houses 743,511 inhabitants corresponding to one fourth of the whole population of the country [25]. The wet season is short, extending from July to September, with little annual variation in the amount of rainfall (50-80 $\mathrm{mm})$. The monthly mean temperatures in Nouakchott varied from $21^{\circ} \mathrm{C}$ to $30.5^{\circ} \mathrm{C}$. Nouakchott is served by five hospitals and nine health centres spread across the city. HG and Nouakchott exhibit every year high level of human migration with Nouakchott residents traveling and staying in Hodh El Gharbi during the months of July, August, September corresponding to the school vacations, and returning to Nouakchott in October and November.

\section{Patients and blood samples collection}

The samples of this study were collected from 676 febrile patients attending Kobeni, Tintane and Aïoun health faciltities in HG region and the 'Centre Hospitalier National', 'Centre Hospitalier Cheikh Zayed' and 'Centre de Santé de Teyarett' in Nouakchott. Before blood sample collection, informed consent was obtained from all participants or in case of children from their parents/legal guardians prior to their enrolment. The study was approved by 'the Direction Régionale de l'Action Sanitaire, DRAS, under the authority of the Mauritanian Ministry of Health.

During the study, if patient presented to health facilities with symptoms consistent with mild malaria, including fever, chills, headache, and a positive slide, they were offered standard ACT as first-line treatment. Among the patients enrolled, 276 (40.8\%) were microscopically confirmed as $P$. falciparum infection. Out of these 114 (40.7\%) patients were from Kobeni, 89(31.7\%) from Tintane and 55(19.6\%) from Aïoun in HG region and 18(6.5\%) patients from Nouakchott. A total of 113 patients were randomly selected from the $276 P$. falciparum positives patients by microscopy. A finger prick blood sample was taken from each consenting patient for thick and thin blood film and 2-3 drops were collected on What$\operatorname{man}^{\odot}$ No. 3 filter paper, dried and stored in individual plastic bag until used for DNA extraction.

\section{Malaria parasite identification}

Thick and thin smears were stained with Giemsa. Parasite density was determined by counting the number of asexual parasites per 200 white blood cells, and calculated per microlitre using the following formula: number of parasites $x 8,000 / 200$, assuming a white blood cell count of 8,000 cells per $\mu \mathrm{l}$ [26]. Absence of malaria parasites in 200 high power ocular fields of the thick film was considered as negative. Obtained data were graded according to parasitaemia: 1, patients with 50-499 parasites/ $\mu \mathrm{l}$; 2, patients with 500-4,999 parasites/ $\mu \mathrm{l} ; 3$, patients with more than 5,000 parasites $/ \mu$ l.

\section{Plasmodium falciparum DNA extraction}

Parasite DNA was extracted, from blood samples blotted on filter paper by methanol method described by Djimde et al. [27]. Briefly, $500 \mu \mathrm{l}$ of methanol was added to a $1.5 \mathrm{ml}$ microcentrifuge tube containing three or four pieces of filter paper and incubated at $15 \mathrm{~min}$ at room temperature. The methanol was poured off and the papers heated at $95-100^{\circ} \mathrm{C}$ in $50-70 \mu \mathrm{l}$ of sterile distilled water for 15 minutes of incubation, during which the tube was gently vortexed every five minutes. The samples were centrifuged twice and the final supernatant was stored at $-20^{\circ} \mathrm{C}$ until used for the amplification reaction. All PCR analyses were conducted in the 'Service de Parasitologie' at the Faculty of Medicine, Université Cheikh Anta Diop, Dakar.

\section{PCR amplification of the $P$. falciparum $m s p-1$ gene}

The highly polymorphic locus, $m s p-1$ block 2 , was used for the genotyping of the $P$. falciparum population using the nested polymerase chain reactions (PCR) technique. The $m s p-1$ primers sequences used in this study are shown in Table 1 [28]. For the primary amplifications (outer PCR), primer pairs corresponding to the flanking sequence of the conserved regions of $m s p-1$ was used (Table 1). The second amplification reactions (nested

\section{Table 1 Sequences of oligonucleotide primers used to genotype msp-1 block 2 allelic types of Plasmodium falciparum isolates from Mauritania}

\begin{tabular}{lll}
\hline $\begin{array}{l}\text { Amplification/ } \\
\text { Primer }\end{array}$ & Sequence & Polymorphism \\
\hline Outer PCR & & \\
Msp1F & 5'AAGCCTTAGAAGATGCAGTATTGAC3' & Conserved \\
Msp1R & 5'ATTCATTAATTCTTCATATCCATTATC3' & \\
Nested PCR & & \\
K1F & 5'AAGAAATTACTACAAAAGGTG3' & K1 family \\
K1R & 5'TGCATCAGCTGGAGGGCTTGCACCAC3' & K1 family \\
& & specific \\
Ro33F & 5'AGGATTTGCAGCACCTGGAGATCT3' & Ro33 family \\
& & specific \\
Ro33R & 5'GAGCAAATACTCAAGTTGTTGCA3' & Ro33 family \\
& & specific \\
Mad20F & 5'TGAATTATCTGAAGGATTGTACGTC3' & Mad20 family \\
& & specific \\
Mad20R & 5'GAACAAGTCGAACAGCTGTTA3' & Mad20 family \\
& & specific \\
\hline
\end{tabular}


PCR) were based on the primary products using allelicspecific primers sets corresponding to $\mathrm{K} 1, \mathrm{RO} 33$ and Mad20 families of $m s p-1$. The primers for $m s p-1$ used in this study are shown in Table 1 . All outer and nested PCR reactions were done in $25 \mu \mathrm{l}$ final volume. For each reaction, $200 \mu \mathrm{M}$ each of deoxyribonucleoside triphosphate (dNTP), $1 \mu \mathrm{M}$ of each primer, $0.5 \mathrm{U}$ of Taq DNA polymerase and PCR Buffer 10X containing $100 \mathrm{mM}$ Tris- $\mathrm{HCl}, \mathrm{pH} 8.3,500 \mathrm{mM} \mathrm{KCl}, 15 \mathrm{mM} \mathrm{MgCl} 2$ and $0.01 \%$ gelatin were used. The outer and the nested amplification were performed on an Applied Biosystem 2720 and PTC-100 Peltier Thermal Cycler respectively using the following conditions: initial denaturation for $3 \mathrm{~min}$ at $94^{\circ} \mathrm{C}$, followed by 30 cycles of $25 \mathrm{~s}$ denaturation at $94^{\circ} \mathrm{C}, 35 \mathrm{~s}$ annealing at $50^{\circ} \mathrm{C}$, and $2 \mathrm{~min} 30$ extension at $68^{\circ} \mathrm{C}$. Final extension was carried out at $72^{\circ} \mathrm{C}$ for $3 \mathrm{~min}$. Nested PCR products were visualized by electrophoresis on $2 \%$ agarose gel (Gibco-BRL) for various lengths of time depending of the predicted size of the PCR products and visualized under UV trans-illumination.

\section{Allelic distribution and multiplicity of infection}

The msp-1 alleles were categorized by their molecular weights and considered the same if their molecular weights were approximately within $10 \mathrm{bp}$ [29]. The multiplicity of infection (MOI), or complexity of infection, was estimated by the average number of PCR fragments per infected individual, as described by Zwetyenga et al. [30].

\section{Statistical analyses}

Statistical analyses were performed using MedCalc for Windows, version 12.3.0.0 (MedCalc Software, Mariakerke, Belgium). Proportions were compared for significance using the $x^{2}$-test. Spearman's rank correlation coefficients were calculated to assess associations between multiplicity of infection, parasite densities and age groups of patients under study. A $P$ value of $\leq 0.05$ was considered indicative of a statistically significant difference.

\section{Results}

\section{Characteristics of the study population}

Out of the 113 randomly selected P. falciparum patients attending health facilities in study sites, $31.8 \%(36 / 113)$ were from Kobeni, 34.5\% (39/113) from Tintane, 17.7\% (20/113) from Aïoun and 16\% (18/113) from Nouakchott (Table 2). Males $(70 / 113 ; 61.9 \%)$ were significantly higher $\left(x^{2}=6.4 ; p=0.01\right)$ than females $(43 / 113 ; 38.1 \%)$. Patients belonging to the age group 5-19 years were the most represented with $55.8 \%$ (63/113) followed by those of 20-39 years of ages with $28.3 \%$ (32/113), patients whose ages $\geq 40$ years with $12.4 \%(14 / 113)$ and children under five years representing $3.5 \%(4 / 113)$.
Table 2 Population characteristics of $P$. falciparum infected patients from different study sites in Mauritania

\begin{tabular}{llllll}
\hline Characteristics & $\begin{array}{l}\text { Kobeni } \\
\mathbf{n}(\%)\end{array}$ & $\begin{array}{l}\text { Tintane } \\
\mathbf{n}(\%)\end{array}$ & $\begin{array}{l}\text { Aïoun } \\
\mathbf{n}(\%)\end{array}$ & $\begin{array}{l}\text { Nouakchott } \\
\mathbf{n}(\%)\end{array}$ & $\begin{array}{l}\text { Total } \\
\mathbf{n}(\%)\end{array}$ \\
\hline Gender & & & & & \\
Male & $20(55.6)$ & $27(69.2)$ & $12(6)$ & $11(61.1)$ & $70(61.9)$ \\
Female & $16(44.4)$ & $12(30.8)$ & $8(4)$ & $7(38.9)$ & $43(38.1)$ \\
Age group & & & & & \\
$<5$ & $1(2.8)$ & $1(2.56)$ & $2(10.0)$ & 0 & $4(3.5)$ \\
$5-19$ & $21(58.3)$ & $23(59.0)$ & $13(65.0)$ & $6(33.3)$ & $63(55.8)$ \\
$20-39$ & $13(36.1)$ & $7(17.95)$ & $4(20.0)$ & $8(44.5)$ & $32(28.3)$ \\
$\geq 40$ & $1(2.8)$ & $8(20.5)$ & $1(5.0)$ & $4(22.2)$ & $14(12.4)$ \\
Total & $36(31.8)$ & $39(34.5)$ & $20(17.7)$ & $18(16.0)$ & $113(100)$ \\
\hline
\end{tabular}

n: number of individuals.

\section{Allelic polymorphism of $m s p-1$}

Allele typing revealed highly polymorphic nature of Mauritanian $P$. falciparum isolates with respect to $m s p-1$ gene. K1, Mad20 and Ro33 MSP1 allele's types were identified. The total number of different sized alleles detected in this sample was 27. Among them, nine for K1 (160-400 bp), 12 for Mad20 (140-400 bp) and six for Ro33 (160-360 bp) allele families were noted. Frequencies of different msp-1 alleles and their combinations and multiplicity of infection are shown in Table 3. The frequency of samples with only K1, Mad20 and Ro33 were $10.6 \%$ (12/113), 2.6\% (3/113) and 4,4\% (5/113) respectively. K1/Mad20, K1/Ro33 and Mad20/Ro33 combinations were found in $21.2 \%$ (24/113), 16.8\% (19/113) and $2.6 \%(3 / 113)$ of samples respectively and $41.6 \%(47 /$ 113) of them harbored all three allelic types. Prevalence of K1, Mad20 and Ro33 allelic types was 90.0\% (102/113), $68.1 \%(76 / 113)$ and $65.5 \%(74 / 252)$ respectively. Multiple clones infections over all study sites was $82.3 \%$ (93/113) with a minimum of $72.2 \%(13 / 18)$ in Nouakchott and a maximum of $90.0 \%$ (18/20) in Aïoun. Multiplicity of infection (MOI) was highest in P. falciparum infected patients enrolled in Aïoun health facility (4.3 genotypes per infection) and lowest in those from Nouakchott health facilities (2.3; mean of three health facilities). However, obtained MOI values were not statistically different from each other $(p=0.56)$. The estimated MOI of all studied area was 3.2 genotypes per infection.

\section{Relationship between multiplicity of infection, age groups} and parasite densities

Age group distribution of $P$. falciparum-infected patients and $m s p-1$ block 2 allelic types is shown in Table 4 . The prevalence of K1, Mad20, Ro33 and their different combinations was significantly higher among patient aged 519 years compared to other age groups $(p<0.05)$ (Table 4$)$. However, no significant correlation between multiplicity 
Table 3 Msp-1 block 2 allelic type frequencies and multiplicity of infection of $P$. falciparum isolates from different study sites in Mauritania

\begin{tabular}{|c|c|c|c|c|c|}
\hline Allelic type & $\begin{array}{l}\text { Kobeni } \\
\text { n (\%) }\end{array}$ & $\begin{array}{l}\text { Tintane } \\
\text { n (\%) }\end{array}$ & $\begin{array}{l}\text { Aïoun } \\
\mathrm{n}(\%)\end{array}$ & $\begin{array}{l}\text { Nouakchott } \\
\text { n (\%) }\end{array}$ & $\begin{array}{l}\text { Total } \\
\text { n (\%) }\end{array}$ \\
\hline K1 & $4(11.1)$ & $6(15.4)$ & $1(5.0)$ & $1(5.5)$ & 12(10.6) \\
\hline Mad20 & $1(2.8)$ & 0 & $1(5.0)$ & $1(5.5)$ & $3(2.6)$ \\
\hline Ro33 & 0 & $2(5.1)$ & 0 & $3(16.7)$ & $5(4.4)$ \\
\hline K1/Mad20 & $7(19.4)$ & $10(25.6)$ & $6(30.0)$ & $1(5.5)$ & $24(21.2)$ \\
\hline K1/Ro33 & $9(25.0)$ & $4(10.2)$ & 0 & $6(32.3)$ & 19(16.8) \\
\hline Mad20/Ro33 & $2(5.5)$ & 0 & 0 & $1(5.5)$ & $3(2.6)$ \\
\hline K1/Mad20/Ro33 & 13(36.1) & $17(43.6)$ & $12(60.0)$ & $5(27.8)$ & 47(41.6) \\
\hline Total & $36(100.0)$ & $39(100.0)$ & $20(100.0)$ & 18(100.0) & 113(100.0) \\
\hline Total K1 & 33(91.6) & $37(94.9)$ & 19(90.0) & 13(72.2) & 102(90.0) \\
\hline Total Mad20 & 23(63.8) & $27(69.2)$ & 19(90.0) & $7(38.8)$ & $77(68.1)$ \\
\hline Total Ro33 & $24(66.6)$ & $23(58.9)$ & $12(60.0)$ & 15(83.3) & $74(65.5)$ \\
\hline Multiclonal isolates & $31(86.1)$ & $31(79.5)$ & 18(90.0) & 13(72.2) & $93(82.3)$ \\
\hline $\mathrm{MOI}$ & 3.1 & 3.2 & 4.3 & 2.3 & 3.2 \\
\hline
\end{tabular}

$\mathrm{n}$ : number of individuals; MOI: multiplicity of infection.

of infections and age groups of patients (Spearman rank coefficient $=0.2 ; p=0.8$ ) was noted. The distribution of K1, Mad20 and Ro33 according to parasitaemia is shown in Table 5. This study found that the individual distribution of K1, Mad20, Ro33 was not significantly different among parasitaemic groups $(\mathrm{p}=0.94)$. Multiclonal isolates was not significantly different neither between $50-499$ parasites $/ \mu \mathrm{l}$ and $\geq 5000$ parasites $/ \mu \mathrm{l}$ $(p=0.09)$, or between 50-499 parasites/ $\mu$ l and 500-4999 parasites $/ \mu \mathrm{l}(\mathrm{p}=0.08)$. However, estimated parasitaemia

Table 4 Distribution of $P$. falciparum msp-1 block 2 allelic type among age groups of $P$. falciparum infected patients from Mauritania

\begin{tabular}{|c|c|c|c|c|c|}
\hline \multirow[b]{2}{*}{ Allelic type } & \multicolumn{4}{|c|}{ Age group (years) } & \multirow[b]{2}{*}{$\begin{array}{l}\text { Total } \\
\text { n (\%) }\end{array}$} \\
\hline & $\begin{array}{l}<5 \\
\text { n (\%) }\end{array}$ & $\begin{array}{l}\text { 5-19 } \\
\text { n (\%) }\end{array}$ & $\begin{array}{l}20-39 \\
\text { n (\%) }\end{array}$ & $\begin{array}{l}\geq 40 \\
\text { n (\%) }\end{array}$ & \\
\hline $\mathrm{K} 1$ & $1(0.9)$ & $8(7.1)$ & $1(0.9)$ & $2(1.8)$ & $12(10.6)$ \\
\hline Mad20 & 0 & $1(0.9)$ & $2(1.8)$ & 0 & $3(2.6)$ \\
\hline Ro33 & 0 & $2(1.8)$ & $2(1.8)$ & $1(0.9)$ & $5(4.4)$ \\
\hline $\mathrm{K} 1 / \mathrm{Mad} 20$ & $1(0.9)$ & $17(15.0)$ & $6(5.3)$ & 0 & $24(23.0)$ \\
\hline $\mathrm{K} 1 / \operatorname{Ro} 33$ & $1(0.9)$ & $10(8.8)$ & $6(5.3)$ & $2(1.8)$ & 19(16.8) \\
\hline Mad20/Ro33 & 0 & $2(1.8)$ & $1(0.9)$ & 0 & $3(2.6)$ \\
\hline K1/Mad20/Ro33 & $1(0.9)$ & $23(20.3)$ & $14(12.4)$ & $9(7.9)$ & 47(41.6) \\
\hline Total & $4(3.5)$ & $63(55.7)$ & $32(28.4)$ & $14(12.4)$ & 113(100.0) \\
\hline Total K1 & $4(100.0)$ & $58(92.1)$ & $27(84.3)$ & 13(92.8) & 102(90.3) \\
\hline Total Mad20 & $2(50.0)$ & $43(68.2)$ & $23(71.8)$ & $9(64.3)$ & $77(68.1)$ \\
\hline Total Ro33 & $2(50.0)$ & $37(58.7)$ & $23(71.8)$ & $12(85.7)$ & $74(65.5)$ \\
\hline Multiclonal isolates & $3(2.6)$ & $52(46.0)$ & $27(23.9)$ & $11(9.7)$ & $93(82.3)$ \\
\hline $\mathrm{MOI}$ & 3.25 & 3.21 & 3.03 & 3.37 & 3.2 \\
\hline
\end{tabular}

$\mathrm{n}$ : number of individuals; MOI: multiplicity of infection. and multiplicity of $P$. falciparum infection was significantly correlated (Spearman rank coefficient $=1 ; p<0.01$ ).

\section{Discussion}

This study was undertaken to assess the polymorphism of the merozoite surface protein-1 block 2 allelic types in $P$. falciparum isolates from different study sites in Mauritania. Plasmodium falciparum is thought to be responsible of nearly $80 \%$ of diagnosed malaria cases in the country [1]. A better understanding of population structure of $P$. falciparum genotypes may be an important element for implementing malaria control strategies in the country. Data showed a relatively high polymorphic nature of $\mathrm{K} 1, \operatorname{Mad} 20$ and Ro33 msp-1 allelic types according to the number of band sizes (27 different PCR products: $9 \mathrm{~K} 1$, 12 Mad20 and 6 Ro33) among Mauritanian P. falciparum isolates. Comparable results were found by Jordan et al. [4]; authors noted 11, 8 and 2 different sized alleles respectively for K1, Mad20 and Ro33 in P. faliparum isolates from malaria patients in Aïoun and Kobeni area located in southern Mauritania. The number of different $m s p-1$ alleles observed among P. falciparum isolates is also comparable to that founded by Konate et al. [31] in the holoendemic area of Dielmo (Senegal) where $33 \mathrm{msp}-1$ alleles were evidenced, but less than that reported by Soulama et al. [29] who founded 41 different sized alleles for $m s p-1$ block 2 region in $P$. falciparum isolates collected from children with uncomplicated malaria infection living in Burkina Faso. The study also revealed the predominance of $\mathrm{K} 1$ type alleles either at study site level or throughout the parasite population compared to Mad20 and Ro33. Similar finding have previously reported among $P$. falciparum isolates from 
Table 5 Distribution of Msp-1 block 2 allelic types among parasitaemic groups of $P$. falciparum infected patients from

\begin{tabular}{|c|c|c|c|c|}
\hline \multirow[t]{2}{*}{ Allelic type } & \multirow[b]{2}{*}{$50-499$ n (\%) } & \multicolumn{2}{|l|}{ Parasitaemia* } & \multirow[b]{2}{*}{ Total } \\
\hline & & $500-4999$ n (\%) & $\geq 5000$ n (\%) & \\
\hline$\overline{\mathrm{K} 1}$ & $1(0.9)$ & $6(5.3)$ & $5(4.4)$ & $12(10.6)$ \\
\hline Mad20 & $1(0.9)$ & $2(1.8)$ & 0 & $3(3.5)$ \\
\hline Ro33 & 0 & $2(1.8)$ & $3(2.6)$ & $5(4.4)$ \\
\hline $\mathrm{K} 1 / \mathrm{Mad} 20$ & $1(0.9)$ & $10(8.8)$ & $13(11.5)$ & $24(21.2)$ \\
\hline K1/Ro33 & $6(5.3)$ & $9(7.9)$ & $4(3.5)$ & 19(16.8) \\
\hline Mad20/Ro33 & 0 & $1(0.9)$ & $2(1.8)$ & $3(2.6)$ \\
\hline K1/Mad20/Ro33 & $2(1.8)$ & $22(19.5)$ & 23(20.3) & $47(41.6)$ \\
\hline Total & $11(9.7)$ & $52(46.0)$ & $50(44.3)$ & 113(100.0) \\
\hline Total K1 & 10(90.9) & $47(90.4)$ & $45(90.0)$ & 102(90.3) \\
\hline Total Mad20 & $4(36.4)$ & $35(67.3)$ & $38(76.0)$ & $77(68.1)$ \\
\hline Total Ro33 & $8(72.7)$ & $34(65.4)$ & $42(84.0)$ & $74(65.5)$ \\
\hline Multiclonal isolates & $9(7.9)$ & $42(37.2)$ & $42(37.2)$ & $93(82.3)$ \\
\hline $\mathrm{MOI}$ & 2.6 & 3.4 & 3.6 & 3.2 \\
\hline
\end{tabular}

$\left({ }^{*}\right)$ parasite/ $\mu \mathrm{l}$ of blood; $\mathrm{n}$ : number of individuals; MOI: multiplicity of infection.

Aïoun and Kobeni [4]. In Dakar, P. falciparum isolates from 48 Senegalese patients hospitalized for malaria showed a prevalence of $68 \%$ for K1 alleles [32]. Most of the isolates were mixed infections $(82.3 \%)$ which harbored more than one allele type. However, prevalence of patients with multiclonal infection was similar in all study sites. A relatively high multiplicity of infections (MOI) was observed among P. falciparum patients either at study site level (2.33-4.25) or over all the study sites (3.22) reflecting the high intensity level of malaria transmission during the study period. When they compared 63 P. falciparum positve samples taken from febrile patients in Aïoun and 110 positive samples from Kobeni, Jordan et al. [4] reported a multiple infections of 1.57 and 2.34, respectively. It is reported that the multiplicity of infection in an infected patient may be due to an important entomological inoculation rate as shown in the Senegal village of Dielmo where patients receive a large number of infective bites [31], or by a single mosquito carrying several parasitic clones in his inoculums [33]. In the context of the present study, it is difficult to speculate on the influence of mosquito inoculum on the multiplicity of infection because no such data is available for the study sites in Mauritania. The MOI values reported in this study are consistent with those reported from regions with high malaria endemicities [34]. Furthermore, there was no association between MOI and age of patients. Investigations conducted in Senegal (Ndiop village where malaria is mesoendemic and seasonal) and Benin (Cotonou), founded that MOI was not affected by age of malaria patients [31,35]. Previous studies regarding the variation of MOI over age have suggested that the influence of age on the multiplicity of infection is highly affected by endemicity of malaria which is probably a reflection of the development of anti-parasite specific immunity [36]. However, this finding contrasting with reports from other locations [29,31,37]. A positive correlation between multiplicity of infection and parasite densities was observed in this study (MOI $=2.6$ 3.6). This is consistent with many reports demonstrating that higher parasite densities increase the probability of detecting concurrent clones in an individual $[18,38]$. This study used $P$. falciparum isolates from patients with clinical symptoms, so that the MOI may be lower than that reported in asymptomatic patients [39]. Many reports showed that MOI would reflect that infected individual has immunity against malaria [31]. Thus, the MOI should be studied in asymptomatic P. falciparum-infected population in Mauritania further, particularly in children. The similarity between $P$. falciparum strains could be explained by population migration between study sites that may allow for exchanges of parasite population. Similar results were noted in many malaria endemic areas [40-42]. The present study is the second report based on molecular epidemiology of $P$. falciparum following the work conducted by Jordan et al. [4] in Aïoun and Kobeni Department of HG region and the first with respect to Tintane department in the same region and Nouakchott, the capital city of Mauritania. It demonstrates that $P$. falciparum populations, at leat in Kobeni and Aïon, had maintained a high level of polymorphism in the $m s p-1$ block 2 region. Studies using a larger number of blood samples collected from different geographic areas in Mauritania are required not only to determine the nationwide 
parasite heterogeneity and detailed malaria epidemiology but also to implement malarial control programmes in this neglected malaria country.

\section{Conclusions}

Plasmodium falciparum isolates from Mauritania exhibited a high degree of genetic polymorphism in $m s p$ - 1 gene and most of the infected patients carried multiple clones of parasites reflecting the high level of malaria endemicity in study sites during malaria transmission season.

\section{Competing interests}

The authors declare that they have no competing interests.

\section{Authors' contributions}

MSOAS conceived of the study, carried out molecular study and performed statistical analysis; MN, BF, OG conceived and supervised molecular analyses and participated in the paper drafting; KML, OAM, carried out the microscopic analysis and participated in statistical analyses; HB, LK, OF, AOMSB conceived of the study, participated in its design and helped to draft and critically analysed the manuscript. All authors read and approved the final manuscript.

\section{Acknowledgements}

This study was supported by the national malaria control program (PNLP) of Mauritania. MSOAS also received a scholarship from the 'Service de la Coopération et de l'Action Culturelle, SCAC' of the France embassy in Nouakchott. Authors thank all health staffs in Tintane, Aioun, Kobeni and Nouakchott for the appreciated efforts to facilitate the field work. Many thanks for all malaria patients for their help and cooperation.

\section{Author details}

'Laboratoire de Biotechnologie, Faculté des Sciences et Techniques, Université des Sciences, de Technologie et de Médecine, Nouakchott, PO Box 5026, Nouakchott, Mauritanie. 'Laboratoire d'Ecologie Vectorielle et Parasitaire, Faculté des sciences et techniques, Université Cheikh Anta Diop, Dakar, Sénégal. ${ }^{3}$ Service de Parasitologie-Mycologie, Faculté de Médecine, Université Cheikh Anta Diop, Dakar, Sénégal. ${ }^{4}$ Service de Parasitologie et de Mycologie, Institut National de Recherches en Santé Publique, BP 695, Nouakchott, Mauritanie. ${ }^{5}$ Unité de Parasitologie, Département d'Infectiologie de Terrain, Institut de Recherche Biomédicale des Armées, BP 7391223 Brétigny-sur-Orge cedex, France. ${ }^{6}$ Aix Marseille Université, Unité de Recherche sur les Maladies Infectieuses et Tropicales Emergentes, UM 63, CNRS 7278, IRD 198, INSERM 1095, Faculté de Médecine La Timone, 27 boulevard Jean Moulin, 13385 Marseille cedex 5 Marseille, France. "Unité de Parasitologie Institut Pasteur, 23 Avenue Pasteur, BP 6010, 97306 Cayenne cedex Guyane, France.

Received: 13 July 2013 Accepted: 21 January 2014

Published: 23 January 2014

\section{References}

1. National Malaria Control Programme: National policy and strategies for malaria control (2006-2010) [in French]. Mauritania: Ministry of Health; 2005.

2. WHO: World malaria report 2008. Geneva: World Health Organization; 2008.

3. Eberl KJ, Jelinek T, Aida AO, Peyerl-Hoffmann G, Heuschkel C, El Valy AO, Christophel EM: Prevalence of polymorphisms in the dihydrofolate reductase and dihydropteroate synthetase genes of Plasmodium falciparum isolates from southern Mauritania. Trop Med Int Health 2001, 6:756-760.

4. Jordan S, Jelinek T, Aida AO, Peyerl-Hoffmann G, Heuschkel C, El Valy AO, Christophel EM: Population structure of Plasmodium falciparum isolates during a epidemic in southern Mauritania. Trop Med Int Health 2001, 6:761-766.

5. Cortes H, Morillas-Marquez F, Valero A: Malaria in Mauritania: the first cases of malaria endemic to Nouakchott. Trop Med Int Health 2003, 8:297-300.

6. Lekweiry KM, Abdallahi MO, Ba H, Arnathau C, Durand P, Trape JF, Salem AO: Preliminary study of malaria incidence in Nouakchott, Mauritania. Malar J 2009, 8:92
7. Lekweiry KM, Basco LK, Salem MS, Hafid JE, Marin-Jauffre A, Weddih AO, Briolant S, Bogreau H, Pradines B, Rogier C, Trape JF, Boukhary AO: Malaria prevalence and morbidity among children reporting at health facilities in Nouakchott, Mauritania. Trans R Soc Trop Med Hyg 2011, 105:727-733.

8. Gasquet M, Delmont J, Le Bras J: Chloroquine-resistant falciparum malaria in Mauritania. Lancet 1995, 346:1556.

9. Monjour L, Richard-Lenoble D, Palminteri R, Daniel Ribeiro C, Alfred C, Gentilini M: A seroepidemiological survey of malaria in desert and semi-desert regions of Mauritania. Ann Trop Med Parasitol 1984, 78:71-73.

10. World Health Organization: http://www.who.int/malaria/publications/ country-profiles/2011/profile_mrt_en.pdf.

11. Genton B, Betuela I, Felger I, Al-Yaman F, Anders RF, Saul A, Rare L, Baisor M, Lorry K, Brown GV, Pye D, Irving DO, Smith TA, Beck HP, Alpers MP: A recombinant blood-stage malaria vaccine reduces Plasmodium falciparum density and exerts selective pressure on parasite populations in a phase 1-2b trial in Papua New Guinea. J Infect Dis 2002, 185:820-827.

12. Takala SL, Escalante AA, Branch OH, Kariuki S, Biswas S, Chaiyaroj SC, Lal AA: Genetic diversity in the block 2 region of the merozoite surface protein 1 (MSP-1) of Plasmodium falciparum: additional complexity and selection and convergence in fragment size polymorphism. Infect Genet Evol 2006 6:417-424.

13. Genton B, Al-Yaman F, Betuela I, Anders RF, Saul A, Baea K, Mellombo M, Taraika J, Brown GV, Pye D, Irving DO, Felger I, Beck HP, Smith TA, Alpers MP: Safety and immunogenicity of a three-component blood-stage malaria vaccine (MSP1, MSP2, RESA) against Plasmodium falciparum in Papua New Guinean children. Vaccine 2003, 22:30-41.

14. Reed ZH, Kieny MP, Engers H, Friede M, Chang S, Longacre S, Malhotra P, Pan W, Long C: Comparison of immunogenicity of five MSP1-based malaria vaccine candidate antigens in rabbits. Vaccine 2009, 27:1651-1660.

15. Kang JM, Moon SU, Kim JY, Cho SH, Lin K, Sohn WM, Kim TS, Na BK: Genetic polymorphism of merozoite surface protein-1 and merozoite surface protein-2 in Plasmodium falciparum field isolates from Myanmar. Malar J 2010, 9:131.

16. Joshi H, Valecha N, Verma A, Kaul A, Mallick PK, Shalini S, Prajapati SK, Sharma SK, Dev V, Biswas S, Nanda N, Malhotra MS, Subbarao SK, Dash AP: Genetic structure of Plasmodium falciparum field isolates in eastern and north-eastern India. Malar J 2007, 6:60.

17. Noranate N, Prugnolle F, Jouin H, Tall A, Marrama L, Sokhna C, Ekala MT, Guillotte M, Bischoff E, Bouchier C, Patarapotikul J, Ohashi J, Trape JF, Rogier C, Mercereau-Puijalon O: Population diversity and antibody selective pressure to Plasmodium falciparum MSP1 block2 locus in an African malaria-endemic setting. BMC Microbiol 2009, 15:219.

18. Peyerl-Hoffmann G, Jelinek T, Kilian A, Kabagambe G, Metzger WG, Von Sonnenburg F: Genetic diversity of Plasmodium falciparum and its relationship to parasite density in an area with differ-ent malaria endemicities in West Uganda. Trop Med Int Health 2001, 6:607-613.

19. Terrientes ZI, Vergara J, Kramer KJ, Herrera S, Chang SP: Restricted genetic diversity of Plasmodium falciparum major merozoite surface protein 1 in isolates from Colombia. Am J Trop Med Hyg 2005, 73:55-61.

20. Khaminsou N, Kritpetcharat O, Daduang J, Charerntanyarak L, Kritpetcharat P: Genetic analysis of the merozoite surface protein-1 block 2 allelic types in Plasmodium falciparum clinical isolates from Lao PDR. Malar J 2011, 10:371.

21. Holder AA, Blackman MJ: What is the function of MSP-1 on the malaria merozoite? Parasitol Today 1994, 10:182-184.

22. Woehlbier U, Epp C, Kauth CW, Lutz R, Long CA, Coulibaly B, Kouyaté B, Arevalo-Herrera $\mathrm{M}$, Herrera S, Bujard $\mathrm{H}$ : Analysis of antibodies directed against merozoite surface protein 1 of the human malaria parasite Plasmodium falciparum. Infect Immun 2006, 74:1313-1322.

23. Pichyangkul $S$, Gettayacamin M, Miller RS, Lyon JA, Angov E, Tongtawe $P$, Ruble DL, Heppner DG Jr, Kester KE, Ballou WR, Diggs CL, Voss G, Cohen JD, Walsh DS: Pre-clinical evaluation of the malaria vaccine candidate $P$. falciparum MSP1(42) formulated with novel adjuvants or with alum. Vaccine 2004, 22:3831-3840.

24. Tanabe K, Sakihama N, Kaneko O, Saito-ito A, Kimura M: A PCR method for molecular epidemiology of Plasmodium falciparum msp-1. Tokai I Exp Clin Med 1999, 23:375-381.

25. National Statistics Office: Statistical yearbooks (1995-2005) [in French]. Mauritania: Ministry of Economic affairs and development; 2006.

26. Shute GT: The microscopic diagnosis of malaria. In Malaria. Edited by Wernsdorfer WH, McGregor I. Churchill Livingstone, Edinburgh: Churchill Livingstone; 1988:805. 
27. Djimde A, Doumbo OK, Cortese JF, Kayentao K, Doumbo S, Diourte Y, Dicko A, Su XZ, Nomura T, Fidock DA, Wellems TE, Plowe CV, Coulibaly D: A molecular marker for chloroquine-resistant falciparum malaria. N Engl J Med 2001 344:257-263.

28. Malaria Research and Reference Reagent Resource Center (MR4): www.mr4.org.

29. Soulama I, Nébié I, Ouédraogo A, Gansane A, Diarra A, Tiono AB, Bougouma EC, Konaté AT, Kabré GB, Taylor WRJ, Sirima S: Plasmodium falciparum genotypes diversity in symptomatic malaria of children living in an urban and a rural setting in Burkina Faso. Malar J 2009, 8:135.

30. Zwetyenga J, Rogier C, Tall A, Fontenille D, Snounou G, Trape JF, Mercereau-Puijalon O: No influence of age on infection complexity and allelic distribution in Plasmodium falciparum infections in Ndiop, a Senegalese village with seasonal, mesoendemic malaria. Am J Trop Med Hyg 1998, 59:726-735.

31. Konate L, Zwetyenga J, Rogier C, Bischoff E, Fontenille D, Tall A, Spiegel A, Trape JF, Mercereau-Puijalon O: Variation of Plasmodium falciparum msp1 block 2 and msp2 allele prevalence and of infection complexity in two neighbouring Senegalese villages with different transmission conditions. Trans R Soc Trop Med Hyg 1999, 93(Suppl 1):21-28.

32. Henry M, Diallo I, Bordesj KAS, Pradines B, Diatta B, M' Baye PS, Sane M, Thiam M, Gueye MP, Wade B, Touze JE, Debonne JM, Rogier C, Fusai T: Urban malaria in Dakar, Senegal: chemosusceptibility and genetic diversity of Plasmodium falciparum isolates. Am J Trop Med Hyg 2006, 75:146-151.

33. Druilhe P, Daubersies P, Patarapotikul J, Gentil C, Chene L, Chongsuphajaisiddhi T, Mellouk S, Langsley G: A primary malaria infection is composed of avery wide range of genetically diverse but related parasites. Am J Clin Invest 1998, 101:2008-2020.

34. Babiker HA, Lines J, Hill WG, Walliker D: Population structure of Plasmodium falciparum in villages with different malaria endemicity in east Africa. Am J Trop Med Hyg 1997, 56:141-147.

35. Issifou S, Djikou S, Sanni A, Lekoulou F, Ntoumi F: Pas d'influence de la saison de transmission ni de l'âge des patients sur la complexité et la diversité génétique des infections dues à Plasmodium falciparum à Cotonou (Bénin). Bull Soc Pathol Exot 2001, 94:195-198.

36. Vafa M, Troye-Blomberg M, Anchang J, Garcia A, Migot-Nabias F: Multiplicity of Plasmodium falciparum infection in asymptomatic children in Senegal: relation to transmission, age and erythrocyte variants. Malar J 2008, 7:17.

37. Smith T, Beck HP, Kitua A, Mwankusye S, Felger I, Fraser-Hurt N, Irion A, Alonso P, Teuscher T, Tanner M: Age dependence of the multiplicity of Plasmodium falciparum infections and of other malariological indices in an area of high endemicity. Trans R Soc Trop Med Hyg 1999, 93:15-20.

38. Farnert A, Arez AP, Babiker HA, Beck HP, Benito A, Bjorkman A, Bruce MC Conway DJ, Day KP, Henning L, Mercereau-Puijalon O, Ranford-Cartwright LC, Rubio JM, Snounou G, Walliker D, Zwetyenga J, Do Rosario VE: Genotyping of Plasmodium falciparum infections by PCR: a comparative multicentre study. Trans R Soc Trop Med Hyg 2001, 95:225-232.

39. Magesa SM, Mdira KY, Babiker HA, Alifrangis M, Farnert A, Simonsen PE, Bygbjerg IC, Walliker D, Jakobsen PH: Diversity of Plasmodium falciparum clones infecting children living in a holoendemic area in north-eastern Tanzania. Acta Trop 2002, 84:83-92.

40. Snounou G, Zhu X, Siripoon N, Jarra W, Thaithong S, Brown KN, Viriyakosol S: Biased distribution of msp1 and msp2 allelic variants in Plasmodium falciparum populations in Thailand. Trans R Soc Trop Med Hyg 1999, 93:369-374.

41. Gómez D, Chaparro J, Rubiano C, Rojas MO, Wasserman M: Genetic diversity of Plasmodium falciparum field samples from an isolated Colombian village. Am J Trop Med Hyg 2002, 67:611-616.

42. Basco LK, Ringwald P: Molecular epidemiology of malaria in Yaounde, Cameroon. VIII. Multiple Plasmodium falciparum infections in symptomatic patients. Am J Trop Med Hyg 2001, 65:798-803.

\section{doi:10.1186/1475-2875-13-26}

Cite this article as: Ahmedou Salem et al:: Polymorphism of the merozoite surface protein-1 block 2 region in Plasmodium falciparum isolates from Mauritania. Malaria Journal 2014 13:26.

\section{Submit your next manuscript to BioMed Central and take full advantage of:}

- Convenient online submission

- Thorough peer review

- No space constraints or color figure charges

- Immediate publication on acceptance

- Inclusion in PubMed, CAS, Scopus and Google Scholar

- Research which is freely available for redistribution

Submit your manuscript at www.biomedcentral.com/submit
() Biomed Central 